\title{
Psychological Distress among Bangladeshi Adults during the Covid-19 Pandemic: A Cross-sectional Study
}

\author{
Md. Abdul Wadood ${ }^{1}$, Md. Monimul Huq², Abu Sayed Md. Al Mamun², Lee-Lee Lai ${ }^{3}$, \\ Suhaili Mohd ${ }^{3}$ and Md. Golam Hossain ${ }^{2 *}$ \\ Medical Centre, University of Rajshahi, Rajshahi- 6205, Bangladesh \\ ${ }^{2}$ Health Research Group, Department of Statistics, University of Rajshahi, \\ Rajshahi-6205, Bangladesh \\ ${ }^{3}$ Department of Orthopaedic Surgery (NOCERAL), Faculty of Medicine, \\ University of Malaya, 50603 Kuala Lumpur, Malaysia
}

KEYWORDS Influential Predictors. Lockdown. Mental Health. Prevalence. Realize Guidelines

\begin{abstract}
The world community including Bangladesh is doing its best to control COVID-19 but its effects on mental health are not being adequately addressed. This study aimed to investigate the psychological distress of COVID-19 among Bangladeshi adults. This cross-sectional study is conducted from 10 to 20 April, 2020, through an online survey and 320 samples were selected by simple random sampling. The frequency distribution revealed that 23.8 percent, 30.9 percent and 45.3 percent of the respondents were suffering from low, moderate, and high levels of psychological distress. Male, professions other than service and housewife, and large family size were the most influential predictors of psychological distress. This study revealed that the psychological impact of the COVID-19 pandemic was remarkably significant in Bangladesh and it might emerge as a serious public health concern. The country should prepare and realize guidelines for psychological crisis management in this regard.
\end{abstract}

\section{INTRODUCTION}

The Coronavirus disease 2019 (COVID-19) emerged as a highly infectious outbreak in Wuhan City of China at the end of 2019 and rapidly spread to other countries. The World Health Organization (WHO) declared it a 'Public Health Emergency of International Concern and a pandemic' (WHO 2020a,b). The numbers of cases and deaths have been increasing everyday and as of September 26, 2020, the disease caused 32,822,128 confirmed infections and 994,503 deaths in 215 countries and territories (Worldometer 2020).

The effects of epidemics or pandemics are multi-faceted complex events that encompass both physical and mental disorders as well as various social and interpersonal problems during and after the outbreak (Norris et al. 2002). The number of mentally affected people crosses the

"Address for correspondence:

Dr. Md. Golam Hossain

Professor of Health Research Group

Department of Statistics

University of Rajshahi

Rajshahi 6205, Bangladesh

E-mail: hossain95@yahoo.com number of people affected by the epidemic itself, and mental health problems may last longer than the epidemic and the psychosocial and economic impacts can be incalculable (Reardon 2015; Shigemura et al. 2020). In light of the experience of previous outbreaks, researches apprehend that the impact of the COVID-19 pandemic on global mental health might also be extensive and long-lasting (Kang et al. 2020). During epidemics/pandemics, a huge number of infections and deaths in a very short period, inadequate healthcare facilities, the fall of the economy, and shortage of supplies create panic among the general population (Miller 2006). Fear also arises when social distancing, isolation, and quarantine are imposed as measures of control of epidemics (Weiss and Ramakrishna 2020). During and after epidemics and pandemics, regardless of exposure, most people experience panic and anxiety of being sick and dying, helplessness, sadness, loneliness, fear, nervousness, anger, and many other psychological mediators arise in association with quarantine, isolation, social distancing, and social and economic fallout ultimately resulting in defined mental health problems (Cheung et al. 2008; Hall and Chapman 2008; Douglas et al. 2009; Xiang et al. 2020; Ahorsu 
et al. 2020; Banerjee 2020). The psychological impacts include depressive illness, stress and anxiety, panic attacks, psychosomatic disorders, PTSD, delirium, psychosis, and suicide (Hall and Chapman 2008; Müller 2015; Tucci et al. 2017).

The world is now busy with the immediate tasks of treatment, control, and prevention of COVID-19 and many countries like Bangladesh cannot pay adequate attention to its psychosocial consequences, though in the meantime, a good number of studies have found significant psychological impacts of the COVID-19 pandemic among the general population. Some studies are available now which focused on psychological effects and correlates of COVID-19. A recent study explored that physical distancing, quarantine, unemployment, and death or illness had negative and media campaigns and global community sense had a positive impact on mental health during the COVID-19 pandemic (Sritharan and Sritharan 2020). Several other studies reported moderate to severe psychological impact in the form of anxiety, stress, depression, insomnia, and so on (Li et al. 2020; Qiu et al. 2020; Rossi et al. 2020; Wang et al. 2020a; Wang et al. 2020b).

Bangladesh identified its first confirmed case of COVID-19 on 8 March, 2020. Since then, the number has continued to increase and as of 26 September, 2020, the country recorded a total of 357,873 confirmed cases and 5,129 deaths (DGHS 2020). But the country has not paid attention yet to the psychological impacts of the outbreak among the general population. The government has not included mental health issues in its plan of combating the COVID-19 outbreak (NPRPCB 2020). Also, COVID-19-related studies are scanty in Bangladesh. A few studies have assessed the knowledge, attitude, practice, and perception toward COVID-19 among students and adults in Bangladesh (Farhana and Mannan 2020; Wadood et al. 2020a; Wadood et al. 2020b). A paper studied a case of COVID19-triggered suicide and xenophobia (Mamun et al. 2020). Another study focused on COVID19-related challenges in Bangladesh (Anwar et al. 2020). A web-based study was conducted on depression and anxiety among university students (Islam et al. 2020a). Another online pilot survey was done on panic and generalized anxiety among Bangladeshi people (Islam et al. 2020b). Another study was done on the impact of COVID-19 on the mental health of children (Yeasmin et al. 2020). So far no study has yet been done on psychological distress among the general adult population in Bangladesh during the COVID-19 pandemic. To fill up the gap, the researches aimed to assess the level of psychological distress among the Bangladeshi adult population during the COVID-19 pandemic and investigate the risk factors associated with it.

\section{Research Questions of this Study}

There are two research questions in this study: (a) what is the prevalence of psychological distress among the adult population in Bangladesh during the COVID-19 pandemic?

(b) what are the associated factors of the psychological distress among the adult population during the COVID-19 pandemic in Bangladesh?

This study was designed to rapidly assess the mental health situation in Bangladesh during the COVID-19 pandemic thereby helping the government and other concerned stakeholders pay due attention to the issue and undertake immediate and appropriate measures. This study was an early assessment of the mental health situation after the outbreak.

\section{METHODOLOGY}

\section{Study Design and Population}

This was a cross-sectional study and Bangladeshi adults were the study population. The researchers collected data from 10-20 April, 2020. During the period, the lockdown was imposed by the government, and physical distancing, staying home, avoiding crowds, and isolation/quarantine were being maintained. As the face-to-face interview was not feasible, an online survey was used for the study.

\section{Sample Size Determination}

The mathematical formula $n=\frac{z^{2} p(1-P)}{d^{2}}$ was used to calculate the sample size for this study, where $\mathrm{n}$ is the number of samples, $\mathrm{z}$ is the value from the standard normal distribution for the selected confidence level (considered $\mathrm{z}=1.96$ for $95 \%$ confidence level), $p=$ the proportion of

J Life Science, 13(1-2): 1-10 (2021) 
the prevalence $=0.50(50.0 \%$ was the assumed highest population proportion prevalence for psychological distress from COVID-19), and $\mathrm{d}=$ the margin of error $=0.05$. The formula delivered that 384 samples would be sufficient for this study. However, a total of 400 samples were selected assuming a 96 percent participation rate.

\section{Sampling Technique}

For selecting samples, researchers first collected 154 email addresses, 286 Facebook IDs, and 110 WhatsApp numbers of Bangladeshi residents from colleagues, friends, and students. It was ascertained that the selected people were of at least 18 years old, encompassing both genders and different socio-economic status, living in different geographical locations in Bangladesh, and not suffering from any diagnosed mental problems before the outbreak. A total of 400 samples were selected using a simple random sampling (by lottery) method for this study.

\section{Questionnaire}

For collecting data, researches used a selfadministered semi-structured questionnaire that had two parts: (i) the first part included questions and statements regarding general, anthropometric, demographic, and socioeconomic information of the participants, and (ii) the second part included six questions of the Kessler Psychological Distress Scale-6 (K-6) to know the psychological state of the participants. First, the questionnaire was drafted in English and translated in Bangla (mother tongue of Bangladesh) to make it easily understandable for the participants. Researchers could not conduct a pilot survey for the shortage of budget and time. The Cronbach Alpha value (0.792) showed that the internal consistency (reliability) of the questionnaire was higher than the acceptance level (good).

\section{Data Collection}

Soft copies of the questionnaire were sent to the selected 400 samples through e-mail, Facebook, and WhatsApp devices. A total of 356 participants sent back filled-up questionnaires with their written consent. The rate of participation was 89.0 percent. However, 36 questionnaires were discarded for incompleteness and finally, 320 questionnaires were available for analysis.

\section{Outcome Variable}

The level of psychological distress among the adult population in Bangladesh during the COVID-19 pandemic was the outcome variable for this study.

\section{Measurement of Psychological Distress}

Researchers used the Kessler 6 Scale (K-6) for measuring psychological distress among the participants (Dadfar et al. 2018). It is the shortened version of the Kessler Psychological Distress Scale (K-10) that was used as an effective tool in population surveys in many countries including non-Western countries (Kessler et al. 2002; Min and Lee 2015). Both K-10 and K-6 were validated as equally sensitive and specific tools (Cornelius et al. 2013; Dadfar et al. 2018). Based on K-6, a five-point Likert scale (i) none of the time, (ii) a little of the time, (iii) some of the time, (iv) most of the time, and (v) all of the time was used to measure the levels of psychological distress and these five levels were assigned to $0,1,2,3$, and 4 points respectively. The assigned points of each of the six responses of the participants were then added to get the total score that ranged from 0 to 24 . Based on the total scores, the level of psychological distress was classified as (i) Low (0-7 scores), (ii) Moderate (8-11 scores), and (iii) High (12-24 scores). For further analysis, psychological distress was categorized into two groups: (i) Low-Moderate (0-11 scores) and (ii) High (12-24 scores).

\section{Independent Variables}

Some demographic and socio-economic factors were considered as independent variables for investigating their associations with psychological distress. The variables were age (younger adult: 18-30 years, middle-aged: 3150 years, older adult: $\geq 51$ years), gender (male, female), residence (urban, rural), type of family (nuclear, joint), education level (no education, primary, secondary, higher), occupation (service, housewife, others), marital status (married, unmarried, others), family's economic status (low: monthly income- $\leq 20000$ Taka, middle: monthly

J Life Science, 13(1-2): 1-10 (2021) 
income-20001-30000 Taka, high: monthly income->31000 Taka), and family members (1-3 members, 4 members, 5 members, $\geq 6$ members).

\section{Statistical Analysis}

In this study, the frequency distribution was used to determine the frequency of sample characteristics and the prevalence of psychological distress. The chi-square test was used to identify the associated factors of psychological distress. The binary logistic regression model was applied to examine the effect of the associated factors on psychological distress. Only the associated factors statistically significant ( $p$-value $<0.05$ ) in bivariate analysis were considered as independent variables for the logistic regression model. Both crude odds ratio (cOR) and adjusted odds ratio (aOR) with $95 \%$ confidence intervals (CI) for significance testing was used for logistic regression analysis. All statistical analyses were carried out using SPSS (IBM Version 22.0).

\section{RESULTS}

\section{Sample Characteristics}

A total of 320 respondents took part in this study. Their mean and median ages were 40.99 (standard deviation $=14.99$ ) years and 42.00 years respectively. Of them, 64.4 percent were male and 35.6 percent were female, and 60.0 percent and 40.0 percent came from urban and rural areas respectively. Near about three-fourth $(72.5 \%)$ of the respondents were currently married, 30.6 percent younger adults, 42.5 percent middle-aged, and 26.9 percent older adults and 60.6 percent were highly educated. More than 78.0 percent of participants were living in nuclear families and 40.0 percent came from families of $\leq 4$ members. About 32.0 percent and 43.4 percent of respondents belonged to high- and low-income families respectively and 32.8 percent of participants were service holders. The detailed characteristics of the participants were shown in Table 1.

\section{Frequency Distribution of the Participants' Responses to K-6 Questions}

Six questions of K-6 were used to measure the psychological distress of COVID-19 among
Table 1: Characteristics of the participants

\begin{tabular}{|c|c|c|}
\hline Variable & Category & $\begin{array}{l}\text { Frequency, } \\
N(\%)\end{array}$ \\
\hline \multirow[t]{3}{*}{ Age } & $\begin{array}{c}\text { Younger adult: } \\
17-30 \text { Years }\end{array}$ & $98(30.6)$ \\
\hline & $\begin{array}{l}\text { Middle-aged: } \\
\text { 31-50 years }\end{array}$ & $136(42.5)$ \\
\hline & $\begin{array}{l}\text { Older adult: } \\
51 \text { and above }\end{array}$ & $86(26.9)$ \\
\hline \multirow[t]{2}{*}{ Gender } & Male & $206(64.40)$ \\
\hline & Female & $114(35.60)$ \\
\hline \multirow[t]{2}{*}{ Residence } & Urban & $192(60.0)$ \\
\hline & Rural & $128(40.0)$ \\
\hline \multirow[t]{2}{*}{ Type of Family } & Nuclear & $250(78.10)$ \\
\hline & Joint & $70(21.90)$ \\
\hline \multirow[t]{3}{*}{ Marital Status } & Married & $232(72.5)$ \\
\hline & Unmarried & $80(25.0)$ \\
\hline & Others & $8(2.5)$ \\
\hline \multirow[t]{4}{*}{ Family Members } & 1-3 members & $43(13.4)$ \\
\hline & 4 members & $128(40.0)$ \\
\hline & 5 members & $71(22.2)$ \\
\hline & $\geq 6$ members & $78(24.4)$ \\
\hline \multirow[t]{3}{*}{$\begin{array}{l}\text { Family's } \\
\text { Economic Status }\end{array}$} & $\begin{array}{l}\text { Low: Monthly income } \\
-\leq 20,000 \text { Taka }\end{array}$ & $139(43.4)$ \\
\hline & $\begin{array}{l}\text { Middle: Monthly income } \\
\text {-20001-30000 Taka }\end{array}$ & $80(25.0)$ \\
\hline & $\begin{array}{l}\text { High: Monthly income } \\
-\geq 30001 \text { Taka }\end{array}$ & $101(31.6)$ \\
\hline \multirow[t]{4}{*}{ Education } & No education & $19(5.9)$ \\
\hline & Primary & $34(10.6)$ \\
\hline & Secondary & $73(22.8)$ \\
\hline & Higher & $194(60.6)$ \\
\hline \multirow[t]{3}{*}{ Occupation } & Service & $105(32.8)$ \\
\hline & Housewife & 63 (19.7) \\
\hline & $\begin{array}{l}\text { Others (students, labors, } \\
\text { health professionals, } \\
\text { retired, unemployed, } \\
\text { and others) }\end{array}$ & $152(47.5)$ \\
\hline
\end{tabular}

Bangladeshi adults. The frequency distribution of the participants' responses to the K-6 questions was presented in Table 2.

\section{Prevalence of Psychological Distress}

The frequency distribution revealed that 23.8 percent, 30.9 percent and 45.3 percent of the respondents were suffering from low, moderate, and high levels of psychological distress However, in two categories, the prevalence of low-moderate and high psychological distress was found to be 54.7 percent and 45.3 percent respectively (Table 3 ).

J Life Science, 13(1-2): 1-10 (2021) 
Table 2: Frequency distribution of the participants' responses to K-6 questions

\begin{tabular}{lccccc}
\hline $\begin{array}{l}\text { Questions: During the last } \\
\text { 30 days, about }\end{array}$ & $\begin{array}{c}\text { None of the } \\
\text { time N (\%) }\end{array}$ & $\begin{array}{c}\text { A little of the } \\
\text { time N (\%) }\end{array}$ & $\begin{array}{c}\text { Some of the } \\
\text { time N (\%) }\end{array}$ & $\begin{array}{c}\text { Most of the } \\
\text { time N (\%) }\end{array}$ & $\begin{array}{c}\text { All of the } \\
\text { time N }(\%)\end{array}$ \\
\hline $\begin{array}{l}\text { 1. How often did you feel } \\
\text { nervous? }\end{array}$ & $36(11.3)$ & $35(10.9)$ & $100(31.3)$ & $80(25.0)$ & $69(21.6)$ \\
$\begin{array}{l}\text { 2. How often did you feel } \\
\text { hopeless? }\end{array}$ & $56(17.5)$ & $39(12.2)$ & $93(29.1)$ & $67(20.9)$ & $65(20.3)$ \\
$\begin{array}{l}\text { 3. How often did you feel } \\
\text { restless or fidgety? }\end{array}$ & $96(30.0)$ & $62(19.4)$ & $128(40.0)$ & $31(9.7)$ & $3(0.9)$ \\
$\begin{array}{l}\text { 4. How often did you feel } \\
\text { that everything was an } \\
\text { effort? }\end{array}$ & $187(58.4)$ & $55(17.2)$ & $53(16.6)$ & $15(4.7)$ & $10(3.1)$ \\
$\begin{array}{c}\text { 5. How often did you feel } \\
\text { so sad that nothing } \\
\text { could cheer you up? }\end{array}$ & $88(27.5)$ & $66(20.6)$ & $93(29.1)$ & $49(15.3)$ & $24(7.5)$ \\
$\begin{array}{l}\text { 6. How often did you feel } \\
\text { worthless? }\end{array}$ & $24(7.5)$ & $31(9.7)$ & $87(27.2)$ & $58(18.1)$ & $120(37.5)$ \\
\hline
\end{tabular}

Table 3: Prevalence of psychological distress among Bangladeshi adults during the COVID-19 pandemic

\begin{tabular}{lcc}
\hline $\begin{array}{l}\text { Psychological } \\
\text { distress }\end{array}$ & Percentage & $\begin{array}{l}\text { Cumulative } \\
\text { percentage }\end{array}$ \\
\hline Low & 23.80 & 23.80 \\
Moderate & 30.90 & 54.70 \\
High & 45.30 & 100.0 \\
\hline
\end{tabular}

Associated Factors of Psychological Distress

The bivariate model (chi-square test) showed that, out of the selected demographic and socioeconomic factors, gender, family members, and occupation were significantly $(\mathrm{p}<0.05)$ associated with psychological distress (Table 4). Table 4 shows that 50.0 percent of male and 36.8 percent of female participants developed psychological distress. Participants coming from 5-membered families were the worst sufferers of psychological distress $(64.8 \%)$ followed by $1-3$-membered families (44.2\%), 4-membered families (40.6\%), and $\leq 6$-membered families (35.9\%). The level of psychological distress was found to be higher $(53.9 \%)$ among the respondents of others profession than those of service (39.0\%) and housewife (34.9\%). Age, residence, marital status, type of family, and education showed no significant association with psychological distress (Table 4).

\section{Effect of the Associated Factors on Psychological Distress}

The associated factors found statistically significant $(p$-value $<0.05)$ in the chi-square test were included in the binary logistic regression analysis to see their effect on psychological distress. Table 5 presents both cOR and aOR results regarding the influential predictors of psychological distress. When the other variables were controlled, adults from $\geq 6$ membered families had higher odds of high psychological distress than those of 1-3-membered families $(\mathrm{aOR}=2.167 ; 95 \% \mathrm{CI}: 0.987-4,757$; $\mathrm{p}<0.05)$. However, if not controlled, respondents of 5-membered families showed more likelihood of having high psychological distress than subjects from 1-3-membered families $(\mathrm{cOR}=2.324 ; 95 \%$ CI: 1.072 - 5.041; $<<0.05)$. It was found that families having $\geq 6$ members were at a higher risk of developing high psychological distress. Respondents of others profession (students, labors, health professionals, retired, unemployed and others) showed a higher vulnerability to high psychological distress compared to service-holders $(\mathrm{cOR}=1.829 ; 95 \% \mathrm{CI}: 1.103-3.031 ; \mathrm{p}<0.05$ and $\mathrm{aOR}=1.858 ; 95 \% \mathrm{CI}: 1.101-3.136 ; \mathrm{p}<0.05)$. Males had higher odds of high psychological distress than females when other variables were not controlled (cOR $=0.583$; 95\% CI: 0.365 - 0.932; $\mathrm{p}<0.05)$. The finding was the same when other variables were controlled but the result did not reach statistical significance $(\mathrm{aOR}=0.630 ; 95 \%$ CI: 0.330 - 1.205; $\mathrm{p}>0.05$ ) (Table 5).

\section{DISCUSSION}

Any sudden epidemic or pandemic inevitably causes psychological problems (Wang et

J Life Science, 13(1-2): 1-10 (2021) 
Table 4: Association of demographic and socioeconomic factors with psychological distress among Bangladeshi adults during the COVID-19 pandemic

\begin{tabular}{|c|c|c|c|c|}
\hline $\begin{array}{l}\text { Variables with } \\
\text { categories }\end{array}$ & $\begin{array}{l}\text { Major psy- } \\
\text { chological } \\
\text { distress, } N \\
(\%)\end{array}$ & $\begin{array}{l}\text { Minor psy- } \\
\text { chological } \\
\text { distress, } N \\
(\%)\end{array}$ & $x^{2}$-value & $p$-val \\
\hline Age & & & 0.957 & 0.632 \\
\hline Younger adult & $48(49.0)$ & $50(51.0)$ & & \\
\hline Middle-aged & $61(44.9)$ & $75(55.1)$ & & \\
\hline Older adult & $36(41.9)$ & $50(58.1)$ & & \\
\hline Residence & & & 0.210 & 0.731 \\
\hline Urban & $85(44.3)$ & $107(55.7)$ & & \\
\hline Rural & $60(46.9)$ & $68(53.1)$ & & \\
\hline Gender & & & 5.127 & 0.026 \\
\hline Male & $103(50.0)$ & $103(50.0)$ & & \\
\hline Female & $42(36.8)$ & $72(63.2)$ & & \\
\hline Marital Status & & & 1.631 & 0.443 \\
\hline Married & $101(43.5)$ & $131(56.5)$ & & \\
\hline Unmarried & $41(51.2)$ & $39(48.8)$ & & \\
\hline Others & $3(37.5)$ & $5(62.5)$ & & \\
\hline Type of Family & & & 0.038 & 0.892 \\
\hline Nuclear & $114(45.6)$ & $136(54.4)$ & & \\
\hline Joint & $31(44.3)$ & $39(55.7)$ & & \\
\hline $\begin{array}{l}\text { Family } \\
\text { Members }\end{array}$ & & & 14.816 & 0.002 \\
\hline $1-3$ members & $19(44.2)$ & $24(55.8)$ & & \\
\hline 4 members & $52(40.6)$ & $76(59.4)$ & & \\
\hline 5 members & $46(64.8)$ & $25(35.2)$ & & \\
\hline$\geq 6$ members & $28(35.9)$ & $50(64.1)$ & & \\
\hline Education & & & 3.768 & 0.285 \\
\hline No education & $6(31.6)$ & $13(68.4)$ & & \\
\hline Primary & $19(55.9)$ & $15(44.1)$ & & \\
\hline Secondary & $36(49.3)$ & $37(50.7)$ & & \\
\hline Higher & $84(43.3)$ & $110(56.7)$ & & \\
\hline Occupation & & & 8.982 & 0.011 \\
\hline Service & $41(39.0)$ & $64(61.0)$ & & \\
\hline Housewife & $22(34.9)$ & $41(65.1)$ & & \\
\hline Others & $82(53.9)$ & $70(46.1)$ & & \\
\hline $\begin{array}{l}\text { Monthly } \\
\text { Family Income }\end{array}$ & & & 0.204 & 0.916 \\
\hline$\leq 20,000$ Taka & $61(43.9)$ & $78(56.1)$ & & \\
\hline $\begin{array}{l}21,000- \\
30,000 \text { Taka }\end{array}$ & $37(46.2)$ & $43(53.8)$ & & \\
\hline$\geq 31,001$ Taka & $47(46.5)$ & $54(53.5)$ & & \\
\hline
\end{tabular}

al. 2020a), and the effects may be long-lasting (Kang et al. 2020). It necessitates immediate and appropriate mental health management measures following a rapid assessment of the actual situation. Researchers designed and conducted the current study considering this necessity in Bangladesh where like India and Nepal, the psychological problems are not given due and timely importance (Koirala et al. 2020) and tried to rapidly assess the psychological impact of the outbreak and investigate the associated factors among the adult population just after the early stage of the outbreak in the country. Researchers were conscious that the psychological distress found in this study might not be considered as diseases, rather these were immediate responses of the participants to a newly emerged unanticipated condition (COVID-19 pandemic). However, researchers could not also neglect them because, over time, some of the problems might ultimately develop disease especially in the case of prolonged exposure.

The respondents participating in this study had no previously-diagnosed mental disorder. After the emergence of the COVID-19 outbreak, as this study revealed, 45.3 percent of them developed high psychological distress and needed interventions. The findings of many other previous studies support this finding. At the initial phase of the pandemic in China, 53.8 percent of subjects reported moderate to severe psychological impact of COVID-19 (Wang et al. 2020a). Another Chinese survey revealed that about 35 percent of people developed mental problems during the outbreak (Wang et al. 2020b). According to a study conducted in India at the early stage of the pandemic, more than 80 percent of the general population was suffering from psychological problems (Roy et al. 2020). Another Indian study found 15 percent mild, 5.5 percent moderate, and 12.7 percent severe psychological impact of COVID-19 in the community (Varshney et al. 2020). In Ethiopia, a study found 45.1 percent of low, 29.4 percent of moderate, 17.6 percent of high, and 7.3 percent of very high psychological distress among the general population (Ambelu et al. 2020). A daily newspaper reported that the National Mental Health Survey of Bangladesh (NMHSB) 2018-19 found 16.8 percent of the Bangladeshi adult population had mental diseases before the COVID-19 pandemic (NEWAGE 2019). A recent online pilot survey reported 37.3 percent of people developed generalized anxiety during the COVID-19 pandemic in Bangladesh (Islam et al. 2020b). Another perception-based study found that 85.6 percent of Bangladeshi people suffered from COVID-19-related psychological distress (Islam et al. 2020c). The findings of all these studies prove that the prevalence of high

J Life Science, 13(1-2): 1-10 (2021) 
Table 5: Effect of the associated factors on psychological distress among Bangladeshi adults during the COVID-19 pandemic

\begin{tabular}{|c|c|c|}
\hline Variables & cOR $(95 \% C I)$ & aOR $(95 \% C I)$ \\
\hline $\begin{array}{l}\text { Gender } \\
\text { Female versus Male }{ }^{\mathrm{R}}\end{array}$ & $0.583(0.365-0.932)^{*}$ & $0.630(0.330-1.205)$ \\
\hline $\begin{array}{l}\text { Family Members } \\
4 \text { versus } 1-3 \text { members }^{\mathrm{R}} \\
5 \text { versus } 1-3 \text { members }^{\mathrm{R}} \\
\geq 6 \text { versus } 1-3 \text { members }^{\mathrm{R}}\end{array}$ & $\begin{array}{l}0.864(0.430-1.736) \\
2.324(1.072-5.041)^{*} \\
0.707(0.331-1.511)\end{array}$ & $\begin{array}{l}1.471(0.680-3.182) \\
1.249(0.687-2,268) \\
3.187(1.607-6.320)^{*}\end{array}$ \\
\hline $\begin{array}{l}\text { Occupation } \\
\text { Housewife versus Service } \\
\text { Others versus Service }^{\mathrm{R}}\end{array}$ & $\begin{array}{l}0.838(0.437-1.604) \\
1.829(1.103-3.031)^{*}\end{array}$ & $\begin{array}{l}1.291(0.545-3.056) \\
1.858(1.101-3.136)^{*}\end{array}$ \\
\hline
\end{tabular}

cOR- Crude Odds Ratio; aOR- Adjusted Odds Ratio; CI- Confidence Interval; " - p-value $<0.05$;

R- Reference

psychological distress was found in this study are justified. Massive media campaigns about the high infectivity and fatality of the disease and publicity of misinformation might create a higher level of psychological impact on the respondents. Disruption of daily life, social functioning and educational, official, and business activities, and fear of losing jobs and earnings might take a high toll on the mental wellbeing of the general population (Shang et al. 2020). The preventive measures like social distancing, staying home, quarantine and isolation might have created a sense of physical and mental detachment from relatives, friends, and the society that might push the people to lose confidence in life ultimately triggering psychological distress in them (Hawryluck et al. 2020; Jeong et al. 2016). Specific types of family and social bonding, and religious and cultural traditions and faiths might also play a role in increasing psychological distress.

In this study, higher odds of the likelihood of COVID-19-related high psychological distress were found among males, bigger family members, and people of other professions like students, laborers, health professionals, unemployed, and retired persons. Males, students, laborers, and health professionals are usually engaged in works and duties outside the home and more exposed to the risk of infection. In addition to fear of being infected, the uncertainty of study due to the continued closure of educational institutions from the very beginning of the outbreak might have created an extra burden of worry and stress for the students. This situation was supported by a study that reported the Chinese students showed a significant association with the impact of COVID-19 on mental health (Zhai et al. 2020). Like the Bangladeshi respondents of this study, the Mexican population showed a higher rate of psychological distress among big family members (Ramírez et al. 2020). Members of bigger families are more sensitive to their wellbeing and at a higher risk of being infected as it is hard for them to follow preventive measures such as physical distancing. These situations might create stress, tension, and anxiety ultimately triggering psychological impact among them (Brooks et al. 2020). Bigger families are usually joint families, and in this study, though not statistically significant, joint family members were found to have high psychological distress in greater numbers $(55.7 \%)$ than nuclear family members. Bigger families need bigger budgets for managing daily requirements and as the COVID-19 pandemic creates a financial crisis for most of the families, this might contribute to increased psychological distress among them. In support of this finding, Ethiopian males and health workers were found to have higher rates of psychological distress (Ambelu et al. 2020). A Chinese study also found higher rates of mental problems among health professionals during the COVID-19 pandemic (Zhang et al. 2020). However, contrary to the present findings, females had higher rates of psychological distress in Indian, Saudi Arabian, and Italian populations (Varshney et al. 2020; AlHanawi et al. 2020; Mazza et al. 2020). A French study found that women and unemployed were more vulnerable to get psychological distress (Chaix et al. 2020).

J Life Science, 13(1-2): 1-10 (2021) 
In this study, researchers presented the prevailing empirical evidence of the psychological distress of Bangladeshi adults during the Covid-19 pandemic. The findings showed that a significantly remarkable number of Bangladeshi adults developed high psychological distress during the COVID-19 pandemic and some demographic and socioeconomic factors were associated with it. Related literature suggest that the prevalence and level of psychological distress and the predictors differ across countries and groups of population based on their respective social, religious, cultural, political, and environmental factors (Mijiritsky et al. 2020). Country-wide research is needed to assess mental health and it's predictors in individual countries to effectively identify the most vulnerable groups of the population during the Covid-19 pandemic. Bangladesh is no exception, and this study provided the groundwork for further research in this sector.

To the researchers' knowledge, this was the first attempt to study the psychological distress among the adult population in Bangladesh during the COVID-19 pandemic. A validated and highly sensitive and specific scale was used to measure psychological distress in this study. Appropriate statistical models were also applied for data analysis. However, there were some limitations too. Though the samples were collected from all over the country from all sections of people, it was not nationally representative in the true sense because only the adults accustomed to email, Facebook, and WhatsApp devices could take part in the study. Secondly, due to lockdown and instructions of staying home and maintaining physical distancing, proper sampling and data collection techniques could not be followed. Thirdly, the self-reported information of the respondents might be biased and exaggerated. Further research is required to examine mental health and psychological distress among different groups of population in the country during the pandemic with larger and nationally representative data and using many other validated instruments.

\section{CONCLUSION}

The aim of this study was to assess psychological distress among Bangladeshi adults during the COVID-19 pandemic and identify the associated factors. A total number of 320 Bangladeshi adults currently living at different locations in the country were considered as samples for this study. Based on the objectives, frequency distribution, chi-square test, and logistic regression models were used in this study for the analysis of data. It was found that 45.3 percent of the adults had high psychological distress, and the male gender, professions other than service and housewife, and large family size were the most influential predictors.

\section{RECOMMENDATIONS}

This is the prime time to address the issue of mental health in Bangladesh without any delay. Firstly, Bangladesh must recognize the psychological impact of the COVID-19 pandemic as a public health concern and include the issue in its national plan of combating COVID-19. Secondly, the country must promulgate principles, fix short and long-term targets, and issue guidelines for psychological crisis management during and after the outbreak. Thirdly, psychiatric and psychological institutions and professionals should operate platforms to strengthen mental health initiatives and provide psychological guidance to the government as well as the general people with special focus on the identified vulnerable groups. Fourthly, all measures should be practical and viable in terms of social tradition, cultural values, and economic capability.

\section{LIMITATIONS}

The main limitation of this study was that only respondents who were available online were considered as sample because people come from different socioeconomic status and not all people are connected through social media. This was a cross sectional study, it was not possible to study the change of psychological distress among Bangladeshi adults of all social strata during the covid-19 pandemic. In this study, the researchers considered only socio-economic, demographic and behavioral factors, some important factors such as biochemical factors were not considered. The researchers recruited only adults (age $\geq 18$ years) but need to investigate psychological distress among adolocents and all levels of students in Bangladesh. More research is required regrading psychological distress among Bangladeshi people.

J Life Science, 13(1-2): 1-10 (2021) 


\section{ACKNOWLEDGEMENT}

Researchers are grateful to relatives, friends, and colleagues for helping us by providing email addresses, Facebook IDs, and WhatsApp numbers of the participants. Researchers also express heartfelt thanks to the participants.

\section{REFERENCES}

Ahorsu DK, Lin C-Y, Imani V, Saffari M, Griffiths MD, Pakpour AH 2020. Fear of COVID-19 scale: Development and initial validation. Int $J$ Ment Health Addiction, 27: 1-9.

Al-Hanawi MK, Mwale ML, Alshareef N, Qattan AMN, Angawi K, Almubark R et al. 2020. Psychological distress amongst health workers and the general public during the COVID-19 pandemic in Saudi Arabia. Risk Manag Healthc Policy, 13: 733-742.

Ambelu A, Birhanu Z, Yitayih Y, Kebede Y, Mecha M, Abata J et al. 2020. Psychological distress during the COVID-19 pandemic in Ethiopia: The need for equal attention of intervention. Research Square Preprint. DOI: https:// doi.org/10.21203/rs.3.rs-33408/v1

Anwar S, Nasrullah M, Hosen MJ 2020. COVID-19 and Bangladesh: Challenges and how to address them front. Public Health, 8: 154.

Banerjee D 2020. The COVID-19 outbreak: Crucial role the psychiatrists can play. Asian J Psychiatr, 50: 102014.

Brooks SK, Webster RK, Smith LE, Woodland L, Wessely S, Greenberg N et al. 2020. The psychological impact of quarantine and how to reduce it: Rapid review of the evidence. Lancet, 395: 912-920.

Chaix B, Delamon G, Guillemassé A, Brouard B, Bibault J-E 2020. Psychological distress during the COVID-19 pandemic in France: A national assessment of at-risk populations. medRxiv Preprint 2020. https://doi. org/10.1101/2020.05.10.20093161

Cheung YT, Chau PH, Yip PS 2008. A revisit on older adults' suicides and Severe Acute Respiratory Syndrome (SARS) epidemic in Hong Kong. Int J Geriatr Psychiatry, 23(12): 123-238.

Cornelius BLR, Groothoff JW, Van der Klink JJL, Brouwe $\mathrm{S} 2$ 2013. The performance of the K10, K6 and GHQ-12 to screen for present state DSM-IV disorders among disability claimants. BMC Public Health, 13: 128.

Dadfar M, Lester D, Momeni SN, Roshanpajouh M 2018. The Kessler Psychological Distress Scale (K6) as a screening instrument: A study of Iranian university students. Ann Depress Anxiety, 5(2): 1097.

DGHS (Directorate General of Health Services), Bangladesh 2020. Coronavirus Covid-19 Dashboard 2020. From <http://103.247.238.92/webportal/pages/covid19.php.> (Retrieved on 30 April 2020).

Douglas PK, Douglas DB, Harrigan DC, Douglas KM 2009. Preparing for pandemic influenza and its aftermath: Mental health issues considered. Int $J$ Emerg Ment Health, 11(3): 137-144.

Farhana KM, Mannan KA 2020. Knowledge and perception towards Novel Coronavirus (COVID 19) in Bangladesh.
International Research Journal of Business and Social Science, 6(2): 76-79.

Hall RCW, Chapman MJ 2008. The 1995 Kikwit Ebola outbreak: Lessons hospitals and physicians can apply to future viral epidemics. Gen Hosp Psychiatry, 30: 446-452.

Hawryluck L, Gold WL, Robinson S, Pogorski S, Galea S, Styra R 2004. SARS control and psychological effects of quarantine, Toronto, Canada. Emerging Infectious Diseases, 10(7): 1206-1212.

Jeong H, Yim HW, Song YJ, Ki M, Min JA, Cho J et al. 2016. Mental health status of people isolated due to Middle East Respiratory Syndrome. Epidemiology and Health, 38: e2016048.

Islam MA, Barna SD, Raihan H, Khan MNA, Hossain MT 2020a. Depression and anxiety among university students during the COVID-19 pandemic in Bangladesh: A web-based cross-sectional survey. PLoS ONE, 15(8): e0238162.

Islam MS, Ferdousa MZ, Potenza MN 2020b. Panic and generalized anxiety during the COVID-19 pandemic among Bangladeshi people: An online pilot survey early in the outbreak. Journal of Affective Disorders, 276: 30-37.

Islam S, Bodrud-Doza M, Khan RM, Haque MA, Mamun MA 2020c. Exploring COVID-19 stress and its factors in Bangladesh: A perception-based study. Heliyon, 6(7): e04399.

Kang L, Li Y, Hu S, Chen M, Yang C, Yang B 2020. The mental health of medical workers in Wuhan, China dealing with the 2019 novel coronavirus. The Lancet Psychiatry, 7: E14.

Kessler RC, Andrews G, Colpe LJ, Mroczek DK, Normand SL, Walters EE et al. 2002. Short screening scales to monitor population prevalence and trends in non-specific psychological distress. Psychological Medicine, 32: 959-956.

Koirala J, Acharya S, Neupane M 2020. Perceived Stress in Pandemic Disaster: A Case Study from India and Nepal. From <SSRN: https://ssrn.com/abstract=3568388> (Retrieved on 5 May 2020).

Li S, Wang Y, Xue J, Zhao N, Zhu T 2020. The impact of COVID-19 epidemic declaration on psychological consequences: a study on active Weibo users. Int $J$ Environ Res Public Health, 17: 2032.

Mamun MA, Griffiths MD 2020. First COVID-19 suicide case in Bangladesh due to fear of COVID-19 and xenophobia: Possible suicide prevention strategies. Asian J Psychiatr, 51: 102073.

Mazza C, Ricci E, Biondi S, Colasanti M, Ferracuti S, Napoli $\mathrm{C}$ et al. 2020. Nationwide survey of psychological distress among Italian people during the COVID-19 pandemic: Immediate psychological responses and associated factors. Int J Environ Res Public Health, 17(9): 3165.

Mijiritsky E, Hamama-Raz Y, Liu F, Datarkar AN, Mangani L, Caplan J et al. 2020. Subjective overload and psychological distress among dentists during COVID-19. Int J Environ Res Public Health, 17(14): 5074.

Miller DA 2006. Pandemics. San Diego CA: Lucent Books.

Min JW, Lee SH 2015. Validation of the K6/K10 scales of psychological distress and their optimal cutoff scores for older Koreans. Int J Aging Hum Dev, 80(3): 264-282.

Müller N 2015. Infectious diseases and mental health. Comorbidity of Mental and Physical Disorders, 179: 99-113.

J Life Science, 13(1-2): 1-10 (2021) 
New Age. 16.8pc Adults, 13.6pc Children Have Mental Disorder in Bangladesh. 8 November, 2019. From $<$ https:// www.newagebd.net/article/90100/168pc-adults136pc-children-have-mental-disorder-in-bangladesh> (Retrieved on 29 April 2020).

Norris FH, Friedman MJ, Watson PJ 2002. 60,000 disaster victims speak: Part II. Summary and implications of the disaster mental health research. Psychiatry, 65(3): 240-260.

NPRPCB (National Preparedness and Response Plan for COVID-19, Bangladesh) 2020. From $<$ https://reliefweb. int/sites/reliefweb.int/files/resources/nprp_covid-19_ v6 18032020.pdf $>$ (Retrieved on 2 May 2020).

Qiu J, Shen B, Zhao M, Wang Z, Xie B, Xu Y 2020. A nationwide survey of psychological distress among Chinese people in the COVID-19 epidemic: Implications and policy recommendations. General Psychiatry, 33: e100213.

Ramírez LPG, Arriaga RJM, Hernández-Gonzalez MA, RocaChiapas JMD 2020. Psychological distress and signs of post-traumatic stress in response to the COVID-19 health emergency in a Mexican sample. Psychology Research and Behavior Management, 13: 589-597.

Reardon S 2015. Ebola's mental-health wounds linger in Africa. Nature, 519: 13-14.

Rossi R, Socci V, Talevi D, Mensi S, Niolu C, Pacitti F et al. 2020. COVID-19 pandemic and lockdown measures impact on mental 1 health among the general population in Italy. An $\mathrm{N}=18147$ web-based 2 survey. medRxiv Prerpint. doi.org/10.1101/2020.04.09.20057802.

Roy D, Tripathy S, Kar SK, Sharma N, Verma SK, Kaushal V 2020. Study of knowledge, attitude, anxiety \& perceived mental healthcare need in Indian population during COVID-19 pandemic. Asian J Psychiatr, 51: 102083. DOI: 10.1016/j.ajp.2020.102083.

Shang LL, Huang YQ, Liu ZR, Chen HG 2017. A crosssectional survey of disability attributed to mental disorders and service use in China. Chinese Medical Journal, 130(12): 1441-1445.

Shigemura J, Ursano RJ, Morganstein JC, Kurosawa M, Benedek DM 2020. Public responses to the novel 2019 coronavirus (2019-nCoV) in Japan: Mental health consequences and target populations. Psychiatry Clin Neurosci, 74(4): 281-282.

Sritharan J, Sritharan A 2020. Emerging mental health issues from the Novel Coronavirus (COVID-19) pandemic. Journal of Health and Medical Sciences, 3(2): 157-162.

Tucci V, Moukaddam N, Meadows J, Shah S, Galwankar SC, Kapur GB 2017. The forgotten plague: Psychiatric manifestations of Ebola, Zika, and emerging infectious diseases. J Glob Infect Dis, 9: 151-156.

Varshney M, Parel JT, Raizada N, Sarin SK 2020. Initial psychological impact of COVID-19 and its correlates in Indian Community: An online (FEEL-COVID) survey. PLOS ONE, 5(5): e0233874.
Wadood MA, Mamun ASMA, Rafi MA et al. 2020a. Knowledge, attitude, practice and perception regarding COVID-19 among students in Bangladesh: Survey in Rajshahi University. medRxiv Preprint. DOI: htt ps:10.1101/2020.04.21.20074757.

Wadood MA, Lee LL, Huq MM, Mamun ASMA, Mohd S, Hossain MG 2020b. Practice and perception of Bangladeshi adults toward COVID-19: A cross-sectional study. Research Square Preprint. DOI: 10.21203/rs.3.rs-29364/v1.

Wang C, Pan R, Wan X, Tan Y, Xu L, Ho CS 2020a. Immediate psychological responses and associated factors during the initial stage of the 2019 coronavirus disease (COVID-19) epidemic among the general population in China. Int $J$ Environ Res Public Health, 17: 1729.

Wang Y, Di Y, Ye J, Wei W 2020b. Study on the public psychological states and its related factors during the outbreak of coronavirus disease 2019 (COVID-19) in some regions of China. Psychology, Health \& Medicine. DOI: $10.1080 / 13548506.2020 .1746817$.

Weiss MG, Ramakrishna J 2006. Stigma interventions and research for international health. Lancet, 367(9509): 536-538. doi: 10.1016/S0140-6736(06)68189-0.

WHO 2020a. Corona Virus. From $<$ https://www.who.int/ health-topics/coronavirus\#t=tab $1>$ (Retrieved on 12 March 2020).

WHO 2020b. WHO Director-General>s Opening Remarks at the Media Briefing on COVID-19 - 11 March 2020. From <https://www.who.int/dg/speeches/detail/whodirector-general-s-opening-remarks-at-the-mediabriefing-on-covid-19---11-march-2020> (Retrieved on 14 April 2020).

Worldometer 2020. COVID-19 Coronavirus Pandemic. From < https://www.worldometers.info/coronavirus/> (Retrieved on 3 April 2020).

Xiang YT, Yang Y, Li W, Zhang L, Zhang Q, Cheung T et al. 2020. Timely mental health care for the 2019 novel coronavirus outbreak is urgently needed. Lancet Psychiatry, 7(3): 228-229.

Yeasmin S, Banik R, Hossain S, Hossain MN, Mahumud R, Salma N et al. 2020. Impact of COVID-19 pandemic on the mental health of children in Bangladesh: A cross-sectional study. Children and Youth Services Review, 117: 105277.

Zhai Y, Du X 2020. Mental health care for international Chinese students affected by the COVID-19 outbreak. Lancet Psychiatry, 7(4): e22.

Zhang W, Wang K, Yin L, Zhao W, Xue Q, Peng M et al. 2020. Mental health and psychosocial problems of medical health workers during the COVID-19 epidemic in China. Psychother Psychosom, 89: 242-250.

Paper received for publication in October, 2020

Paper accepted for publication in March, 2021 